\title{
Da injúria da preta Sabina para o contexto escravista na segunda metade do século XIX (Cachoeira/RS) ${ }^{1}$
}

From the Injuries of the Black Sabina to the slaver context of the second half of the Nineteenth Century (Cachoeira/RS)

\section{Marina Camilo Haack}

Universidade do Vale do Rio dos Sinos - UNISINOS - São Leopoldo - Rio Grande do Sul - Brasil

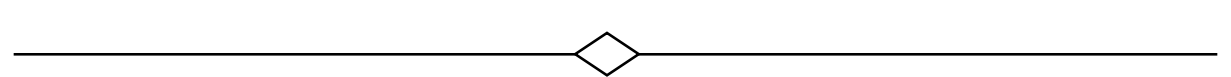

Resumo: Os processos criminais são excelentes fontes que dão acesso ao cotidiano de sujeitos que muitas vezes deixaram poucos vestígios de sua existência, além disto, através deles podemos tentar compreender o contexto e a sociedade em questão. Neste trabalho, utilizaremos o caso de uma escravizada acusada de injuria a um Guarda Nacional, tornando-se ponto de partida para a análise de outras questões que compunham aquele cenário, como a Guerra do Paraguai, a população da vila de Cachoeira e o processo de abolição gradual, que carregava mudanças no discurso jurídico da época.

Palavras-chave: Processo crime. Escravidão. Cachoeira/RS.

Abstract: The criminal processes are excellent sources that allow access to the daily life of individuals who, many times, have left a few traces from their existence and, besides that, through them, we can try to comprehend the context and the society studied. In this work, we will utilize the case of a slave accused of making injuries to a National Guard, becoming the starting point to the analysis of other topics that composed that scenario, as the Paraguay War, the population of the Cachoeira village and the process of gradual abolition carrying changes in the juridical discourse of this period.

Keywords: Criminal process. Slavery. Cachoeira/RS

\footnotetext{
${ }^{1}$ Este artigo foi originalmente escrito para a disciplina "Metodologias e Fontes na História Social" do Programa de pós-Graduação em História da Universidade do Vale do Rio dos Sinos (UNISINOS), ministrada pelos professores doutores Paulo Roberto Staudt Moreira e Maíra Ines Vendrame. Assim, muitas referências constantes neste artigo são provenientes da respectiva disciplina.
} 


\section{Introdução}

Para este trabalho foi selecionado um processo criminal formado em 1867 na vila de Cachoeira/RS. O documento é curto, cerca de 25 folhas, e versa sobre um caso "comum" de injúria, além de apresentar uma letra difícil de ser compreendida, exigindo um árduo trabalho de paleografia $^{2}$. Contudo, o caso apresentou uma forte possibilidade de se discutir o contexto da época, marcado pela Guerra do Paraguai e pela intensificação do debate abolicionista. Naquele momento já havia se passado quase duas décadas da proibição do tráfico de escravizados para o Brasil, e a Lei do Ventre Livre já começava a ser discutida mais incisivamente, compondo um período de intensa movimentação política e ideológica no país ${ }^{3}$.

Os processos criminais, como apontou o historiador Carlo Ginzburg, "devem ser lidos como produtos de uma relação especifica e profundamente desigual" (GINZBURG, 2007, p, 287). As relações desiguais de que falava Ginzburg, entre inquisidores e camponeses acusados de heresia, contribuem para elucidar as especificidades desta fonte, que resulta do julgamento de sujeitos que estavam em situação de desvantagem hierárquica: "Para decifrá-los, devemos aprender a captar por trás da superfície lisa do texto um sutil jogo de ameaças e medos, de ataques e retiradas. Devemos aprender a desembaraçar os fios multicores que constituíam o emaranhado desses diálogos" (GINZBURG, 2007, p, 287).

O autor ao pontuar as implicações de utilizar os processos inquisitoriais, entre outros documentos, afirma que não existem textos neutros: "mesmo um inventário notarial implica um código que temos de decifrar" (GINZBURG, 2007, p, 288). Assim, neste

\footnotetext{
2 Processo Criminal. APERS. N 3127, M 8, E 56.

3 Sobre as últimas décadas do escravismo no Brasil, ver: CHALHOUB, Sidney. Visões da Liberdade: uma história das últimas décadas da escravidão na corte. São Paulo: Cia. das Letras, 1990; ARAÚJO, Thiago. Escravidão, fronteira e liberdade: políticas de domínio, trabalho e luta em um contexto produtivo agropecuário (Vila da Cruz Alta, Província do Rio Grande de São Pedro, 1834-1884). Porto Alegre, Dissertação (Mestrado em História). PPGH-UFRGS, 2008; PERUSSATTO, Melina. Como se de ventre livre nascesse: experiências de cativeiro, parentesco, emancipação e liberdade nos derradeiros anos da escravidão - Rio Pardo, RS, c.1860- c.1888. São Leopoldo, Dissertação (Mestrado em História), PPGHUNISINOS, 2010
}

trabalho, há um esforço de perceber o que motivou a construção do discurso, bem como a contextualização deste discurso e das demais fontes utilizadas para esta análise, como por exemplo: o objetivo de quantificar uma população, como veremos ao utilizar os censos; o objetivo de construir regras de convivência, como veremos no Código de Posturas; e até o objetivo de se atribuir a falta de consciência para justificar atos que quebram uma determinada ordem hierárquica e social.

Há, portanto, a necessidade de se ter alguns cuidados na utilização de fontes como processos criminais dentro dos estudos sobre escravidão. Tal fonte tem sido muito utilizada com vias de se conseguir ter acesso ao cotidiano de sujeitos escravizados, o processo pode evidenciar motivações, sentimentos, ideias de justiça e injustiça e demais questões que envolviam aqueles indivíduos. Contudo, como alerta Ginzburg, estes documentos são "contaminados" pelo escrivão e pelos sujeitos que faziam o interrogatório, o historiador precisa estar atento a estes atenuantes.

Maíra Vendrame em seu estudo sobre as redes de sociabilidade, honra familiar e práticas de justiça dos imigrantes italianos, utilizou processos criminais, entre outras fontes para compor sua análise, esclarece que ao utilizar estes documentos:

Pretendemos trazer elementos para avançar no entendimento sobre a sociedade rural italiana formada no sul do Brasil a partir do final do século XIX. Os conflitos e crimes ocorridos na região colonial não serão avaliados pelo exótico e o extraordinário que deles se poderá vislumbrar. A ideia é apreender o tipo de racionalidade que regia os comportamentos individuais e familiares, as práticas de justiça local e ajustes extrajudiciais a fim de perceber como se dava a recomposição do equilíbrio social nas comunidades, bem como aspectos da cultura dos imigrantes, maximamente questões relacionadas à honra e à moral (VENDRAME, 2016, p. 35).

Assim, no mesmo sentindo que Vendrame buscou dar ao uso dos documentos judiciários em sua pesquisa, tentaremos dar nesta breve análise do caso de Sabina. Provavelmente muitos outros casos de injuria ocorreram em Cachoeira, envolvendo 
sujeitos de condições diversas, no entanto, a peculiaridade que daremos ao caso, será o contexto dele extraído, e como a relação entre moral, justiça e escravidão podem ser vislumbradas através deste documento. Tendo em vista que estas fontes evidenciam "práticas sociais frequentes e ações coletivas que correspondem a determinado sistema de valores, [...] apresentam sinais que permitem a reconstrução de uma realidade histórico-cultural" (VENDRAME, 2016, p. 31). Pode-se, portanto, tentar compreender as relações de sujeitos que viviam em um mesmo contexto, mas em lugares sociais distintos, e como o discurso jurídico e a prática de justiça se dava nestes casos, principalmente onde se percebe o atrito entre a justiça amparada pelas leis, e as práticas de justiça validadas pelo costume em seu uso social.

Keila Grimberg nos fornece dicas preciosas sobre a análise deste tipo de fonte, que devem ser compreendidas com cuidado e atenção, e assimiladas dentro do seu contexto de produção. A autora corrobora com o que falamos no início deste trabalho: os processos criminais são fontes primordiais para recuperar o cotidiano dos trabalhadores, seus valores e formas de conduta (GRIMBERG, 2009, p. 126). E as decisões finais encontradas nesses documentos, seja pela postura dos profissionais do direito ou mesmo pelo pronunciamento dos juízes de fato (o corpo de jurados), revelam igualmente o conjunto moral que norteava o aparelho judiciário da época. Portanto, os processos criminais são documentos frutos de atos criminosos, assim considerados pela visão do Estado (GRIMBERG, 2009, p. 123).

Sobre os usos que damos aos processos criminais, Grimberg alerta que é impossível descobrirmos o que realmente se passou na história reconstituída nos autos: "Por mais que seja a tentação, é importante lembrar, sempre, que nós não somos os detetives. Ou melhor, somos um tipo diferente de detetive, cujo objetivo não é descobrir o culpado de um crime", sabendo que "ele [o documento] é sempre a construção de um conjunto de versões sobre um determinado acontecimento" (GRIMBERG, 2009, p. 128). Nossa função, a dos historiadores, não é descobrir o culpado, tão pouco julga-lo, mas extrair dali as mais diversas facetas de uma sociedade que buscamos conhecer. E ainda que a verdade ou o fato em sua plenitude jamais possam ser alcançados, nos agarramos a algumas certezas, que fazem parte do nosso ofício.

Como alguém submetido a escravidão, um crime contra a humanidade, poderia ser condenado à morte como criminoso? Como poderia Tomás ser culpado por infringir regras de uma sociedade da qual não era sócio? Como o escravo, considerado como coisa, podia ter descumprido o contrato social pactuado por pessoas - assim definidas por terem nascido iguais e livres? (FERREIRA, 2011, p. 20)

Esta passagem faz parte do texto de defesa que Joaquim Nabuco escreveu no caso do escravizado Tomás. Sem querer entrar em detalhes sobre o caso, considero a passagem importante para o objetivo deste texto. Sabina é a protagonista deste artigo, uma preta natural da África, que foi indiciada no dia 30 de agosto de 1867 por injúria. Não sabemos muito mais detalhes sobre ela do que os que foram informados no processo, ela não sabia sua idade e tinha como profissão os serviços domésticos. E claro, não tinha Joaquim Nabuco como seu advogado. Mas a defesa esforçou-se para livrá-la da pena a que foi submetida, mais pela causa do senhor do que da própria Sabina. O curador alegou que Sabina não tinha consciência do ato que praticara, e era, portanto, um ato de ignorância e sem maldade. Contudo, assim como Tomás, Sabina infringiu as regras de uma sociedade da qual não era sócia, podia ser considerada coisa e sem consciência pelo curador, mas o fato que defendo, é que Sabina sabia muito bem o que queria no dia em que injuriou Justino José dos Anjos.

Como diz a sabedoria popular da malandragem - é assim que Drauzio Varella se referia aos presidiários do antigo Carandiru: "Numa cadeia, ninguém conhece a moradia da verdade" (VARELLA, 2005, p. 8). Por ironia, o cenário do crime cometido por Sabina era a cadeia de Cachoeira/RS. A malandragem, todavia, criou um ditado que se aplica para além dos muros da cadeia, para os muros da 
academia, e assim como lá, aqui também ninguém conhece a moradia da verdade.

Quem passava pela Praça da Igreja naquele 30 de agosto de 1867 deve ter se assustado ao ouvir as palavras de ordem da preta Sabina: filha da puta, corno, ladrão! A discussão vinha da cadeia da cidade, que era também o prédio da Câmara e do Júri, o Paço Municipal. Em função da marcha do corpo policial da província para a Guerra do Paraguai, aqueles prédios públicos eram guarnecidos pela Guarda Nacional. As ofensas proferidas pela preta Sabina receberam como reprimenda um conselho do Guarda Nacional Januário Olímpio, para que ela dali se retirasse. Conselho este ignorado, Sabina queria acertar as contas com o, também, guarda nacional Justino José dos Anjos, esse sim alvo das suas descomposturas.

O prédio que abrigava a cadeia de Cachoeira, era também ocupado pela câmara e pelas sessões do júri, e havia sido concluído apenas três anos antes de Sabina enfrentar os Guardas Nacionais que ocupavam o prédio. Antes disso, a prefeitura alugava de particulares os espaços para servirem de cadeia e câmara, e mesmo após a conclusão do novo espaço, em 1864, a pedido de Dom Pedro II o local ainda serviu como hospital militar durante algum tempo. Embora a Guerra do Paraguai estivesse distante de Cachoeira, o prédio abrigou muitos feridos de guerra antes de serem encaminhados para outros hospitais. Apenas em 1865 o prédio foi efetivamente ocupado para o motivo que fora construído.

O leitor deve estar se perguntando qual motivo levou Sabina a se expor ao risco de xingar uma autoridade em seu próprio local de trabalho. Justino devia 14 vinténs à preta, e o desespero de tal atitude deve ter se dado pela pressa em receber o valor, considerando ser uma sexta-feira do último dia do mês, e a necessidade de repassar esse valor para quitar outra dívida que, talvez, a preta tivesse. Também cabe pensar que se Sabina se expôs a ridicularizar publicamente o seu devedor, sabedora que era da desigualdade dos lugares sociais que ambos ocupavam, é que tal acontecimento que nos chegou pelo documento judiciário, deve ter sido parte de um litígio mais longo, no percurso do qual ela não conseguiu a devolução de seu empréstimo por vias pacíficas. A ofensa pública do contendor foi um recurso, digamos, legítimo, daquela assimétrica contenda comunitária.

O fim do tráfico de escravos em 1850, e as discussões que precediam a Lei do Ventre Livre na década de 1860, além do crescente debate de uma eminente abolição, ou como os grandes senhores queriam, o mais gradual possível, deve ter alimentado o sentimento de uma possível "inversão de forças" ${ }^{4}$. A chegada de imigrantes alemães em Cachoeira no ano de 1857 e posteriormente um novo fluxo em 1877 de italianos, previa um fenômeno triplo: de reposição da mão de obra de escravizados que tenderia a diminuir nas décadas finais de escravidão, o branqueamento da população, que também foi uma preocupação conforme o alvorecer do século $X X$, e a necessidade desses imigrantes europeus de procurarem em terras brasileiras condições melhores de sobrevivência. Conforme Jonas Vargas:

Entre 1815 e 1914, a população da Europa cresceu em altos índices, ultrapassando o seu dobro. Em 1800, por exemplo, ela possuía 187 milhões de pessoas e, em 1900, tinha ultrapassado os 400 milhões. As consequências sociais deste crescimento demográfico associado a momentos de crise econômica e política foram o pauperismo, o desemprego crônico e a baixa dos salários, levando parte de sua população a migrar para terras que prometiam uma vida melhor (VARGAS, 2013, p. 171).

Segundo Botelho (2005) a construção dos censos populacionais está diretamente ligada ao projeto de construção nacional, que fazia parte dos anseios das elites brasileiras, além do Estado. A primeira tentativa de um recenseamento nacional bem sucedida se deu em 1872, e estava diretamente

\footnotetext{
4 Refiro-me aqui a formação do conceito de Nação e o sentimento de cidadania a ele vinculado, crescentes na segunda metade do século XIX, de que fala Botelho (2005), além do crescente aumento de livres de cor na sociedade, outrora em condição subalterna, em um senso comum da época. Para uma análise do contexto em que foram planejados os grandes recenseamentos populacionais do período do Brasil Imperial ver: BOTELHO, Tarcísio R. População e nação no Brasil do século XIX. USP: 1998. Tese de Doutorado em História; BOTELHO, Tarcísio R. Censos e construção nacional no Brasil Imperial. Tempo Social. Revista de Sociologia da USP, São Paulo, v. 17, n.1, p. 321-341, 2005.
} 
ligado a discussão do fim da Guerra do Paraguai, que havia contribuído para a formação de uma noção de identidade nacional nos últimos anos, e da importante Lei do Ventre Livre promulgada no ano anterior.

Além disto, outros interesses movimentavam a necessidade de um censo a nível nacional, estas motivações estavam ligadas a políticas públicas como: fim da escravidão, questão eleitoral e o reconhecimento da característica da população que compunham a nação (BOTELHO, 2005, p. 325). Os quadros do censo de 1872 foram pensados a partir destas questões, reconhecer as habilidades e as fraquezas da nação, ademais, os levantamentos censitários estavam na esteira das discussões das ditas nações civilizadas.

Como ressalta Botelho o censo de 1872 refletiu um retrato daquilo que a elite imperial do Brasil queria ver: "uma nação homogênea quanto aos aspectos culturais, mas hierarquizada quanto à sua condição social e quanto à cor. A preocupação com a cor seria o foco das indagações, nas décadas seguintes, acerca dos destinos da nação" (BOTELHO, 2005, p. 336). Estas indagações a que o autor se refere diz respeito as discussões eugenistas sobre a miscigenação e a cor do povo brasileiro no tocante do século $X X$.

Segundo este censo, Cachoeira contava com uma população de 11.756 habitantes. Destas 9.620 eram livres (82\%) e 2.136 escravizados (18\%). Há uma queda na porcentagem de escravizados em Cachoeira, ainda que um aumento em números absolutos se comparado com o censo de 1859, que compunha o total de 5.169 habitantes, dos quais: 3.456 eram livres (67\%), 1.628 cativos (31\%) e libertos $85(2 \%)^{5}$.

Neste censo de 1872, é interessante notar a presença de estrangeiros de nacionalidade alemã, como dito acima, Cachoeira foi uma das vilas receptoras destes imigrantes, que compunham 1.217 habitantes dos 1.460 estrangeiros. Temos ainda 94 pessoas de origem africana, que constam como

\footnotetext{
${ }^{5}$ Alguns autores como Araújo (2008) apontam a subavaliação da presença escrava neste censo de 1872. Fonte: Mapa Estatístico da população da província classificada por idades, sexos, estados e condição com o resumo do total de livres, libertos e escravos (FAGUNDES, 2009: p.49).
}

libertas, contudo, deve-se ressaltar que provavelmente este dado possuí alguns problemas de subavaliação da presença escrava.

Das profissões vamos abordar apenas algumas categorias: 1.164 tinham como profissão os serviços domésticos, destas, 914 (78,5\%) tinham como condição jurídica escravos e a maioria eram mulheres (65\%), 3 eram militares e 16 empregados públicos. Mais da metade da população não possuía profissão (56\%) segundo o censo, neste número estão inclusas as crianças.

Sabina em interrogatório disse ter como profissão os serviços domésticos e ser natural da Costa da África. Jonas Vargas desmembrou o grupo de escravizados ligados ao trabalho de serviços domésticos nas seguintes ocupações: as mucamas, lavadeiras, cozinheiras, engomadeiras e copeiros (VARGAS, 2013, p. 211). Assim como em Cachoeira, no lócus do autor, em Pelotas, as mulheres também compunham o maior número nesta atividade. Como no censo de 1872 não haviam africanos escravizados, talvez Sabina tenha conquistado sua alforria, que não foi identificada no catálogo de cartas do APERS, ou talvez tenha migrado para outra localidade e vendida, não sabemos que rumo sua vida tomou após $1867^{6}$. O que temos são pistas daquele período de julgamento, e com isso a necessidade de se traçar o contexto da época.

Além disto, segundo Sandra Graham (GRAHAM, 2005) e Jonas Vargas (2013), as mulheres empregadas nestas atividades ligadas ao cuidado do senhor e de sua família, podiam ter acesso a comida, vestimenta e moradia de melhor qualidade. O número de escravizados designados para estas funções também era um indicativo do poder econômico do senhor. Este tipo de atividade, que não estava diretamente ligado ao serviço no campo, podia gerar um tipo de mobilidade diferente dos demais, a própria atividade na lavagem de roupa era um indicativo disto, pois demandava um deslocamento maior (e potencializava a autonomia)

\footnotetext{
${ }^{6}$ Ainda é necessário buscar mais informações de outras fontes para fazer o cruzamento. Pode ser que Sabina tenha sido alforriada em algum inventário da família senhorial, ou mesmo falecido. Serão aprofundados para as próximas pesquisas estas informações.
} 
daquelas mulheres. Provavelmente, caso a propriedade do senhor de Sabina não fizesse parte do meio urbano de Cachoeira, ela poderia estar aproveitando desta mobilidade para fazer a cobrança da dívida de Justino. Talvez uma ida ao mercado local, algum trabalho no centro da cidade a mando do senhor, enfim, são hipóteses levantadas a partir das pistas.

Nos chama atenção, também, o pequeno número de militares na cidade. Isto pode ser um indicativo de um maior número de Guardas Nacionais envolvidos nas atividades de policiamento da Vila, já que o Guarda Nacional Justino foi chamado de "empregado público" no processo. Dos empregados públicos há também um pequeno número de sujeitos. Seria necessário fazer um levantamento maior sobre as designações de tais atividades para compreender os ofícios. Mas, fica aqui o estranhamento de tais profissões e como foram designadas no processo e no censo para serem aprofundadas futuramente.

\section{A Guarda Nacional e o contexto da Guerra do Paraguai}

A força armada do Brasil, neste contexto, era composta pelo Exército regular, marinha e pela Guarda Nacional, chamada milícia cidadã (MUGGE, 2016). Estes indivíduos deviam ter entre 21 e 60 anos e uma fonte de renda mínima anual de 100 a 200 mil réis (MUGGE, 2012). A formação da guarda significava uma saída para um exército numeroso e para a contenção de custos com soldados ${ }^{7}$. Eram, portanto, sujeitos que tinham posses e ao ingressar na Guarda também se destacavam socialmente, Miquéias Mugge salienta que estes sujeitos podiam ter "maior margem de ação social" a ponto de legitimar o ilícito (MUGGE, 2012, p. 13). Durante a Guerra do Paraguai, a Guarda Nacional riograndense teve fundamental importância "em 1867, foi maior que todas as contribuições das províncias do Ceará e do Mato Grosso, quase igualando-se à de São Paulo" (MUGGE, 2016, p. 135). Portanto,

\footnotetext{
${ }^{7}$ A guarda nacional brasileira foi inspirada na Guarda francesa e foi criada no contexto de revoltas do período regencial.
}

compunham um grande corpo dentro do front de batalha.

O sujeito responsável pela voz de prisão de Sabina foi o cabo alvorada Ezequiel Rodrigues Florence comandante da Guarda da Cadeia. A denominação pode indicar que o cabo fazia o turno da noite ao amanhecer, como não temos o horário do momento em que Sabina foi procurar o acerto de contas com Justino, talvez isto indique ser o período da manhã, daquela sexta-feira ${ }^{8}$. O que pode levantar algumas hipóteses sobre a cobrança ter sido feita justamente naquele dia, quem sabe ela soubesse que o seu devedor recebia o seu soldo naqueles dias próximos. Outra possibilidade ainda, é que Sabina fosse alugada por seu senhor e tinha as datas combinadas para estes pagamentos. Contudo, não há referência a estas suposições no documento.

A Guerra do Paraguai mobilizou soldados do Brasil inteiro, o conflito começou em 1864 e estendeu-se até 1870. Segundo Moreira o combate foi impopular e demandou a mobilização da imprensa e do governo para construir na população o sentimento de necessidade do conflito, e o mais importante, poder mobilizar o recrutamento de homens necessários (MOREIRA, 2003, p. 216). A circulação de Dom Pedro II pelo Brasil tinha essa função de mobilizar e unificar os brasileiros na causa. A propaganda empenhada pelo imperador em sua visita ao Rio Grande do Sul em 1865 era sobre o recém criado corpo de Voluntários da Pátria, cujo voluntário número um, era ninguém menos que o próprio Dom Pedro II.

Montado a cavalo, comendo churrasco e usando expressões locais, Dom Pedro II passeou pela campanha sulina visitando cidades e acampamentos de Corpo de Voluntários da Pátria, procurando motivar com a sua presença os populares que agora fardados deviam defender a honra do país que the negava o foro de cidadãos quando paisanos (MOREIRA, 2003, p. 217).

\footnotetext{
${ }^{8}$ Não encontrei nada referente a "alvorada" nas denominações do exército, o colega Dionathan Kirst que conhece o funcionamento militar me ajudou nesta suposição de turno. Segundo ele, alvorada seria o horário em que o militar se apresenta, indicando que ele trabalhava de noite e apresentavase de manhã.
} 
Os voluntários deviam ter entre 18 e 50 anos de idade e, além da participação de europeus imigrantes, que formavam o corpo de soldados na guerra, homens negros escravizados e libertos também estiveram presentes no front. É de 1867 a famosa imagem paraguaia, de cunho racista, publicada no jornal El Centinela que representava três macacos, entre eles o maior Dom Pedro II, que fazia referência aos soldados negros recrutados pelo Brasil. Segundo André Toral, já em 1865 o Paraguai também recrutava escravos para recompor os homens adoecidos e mortos. No Brasil, o recrutamento voluntário, que se dava de forma compulsória nas províncias, tornou-se uma piada, e lutar na guerra logo se tornou sinônimo de pobreza, uma vez que os que possuíam condições davam um jeito de escapar-se do alistamento.

Torna-se claro que os limites da cidadania efetiva do império igualam os escravos e despossuídos como material humano disponível para a guerra. A Guarda Nacional, apesar da inspiração liberal do modelo francês, terminou a serviço de oligarquias, alistando compulsoriamente qualquer um, desde que pobre ou adversário político. Os Voluntários da Pátria, por seu lado, dada a ausência de entusiasmo popular depois da fase inicial da guerra, também receberam em suas fileiras escravos e substitutos de toda sorte (TORAL, 1995, p. 293). [Grifos do autor]

Foi neste contexto que, em 1865, Dom Pedro II fez sua visita à Cachoeira e solicitou que o recém construído casarão da cadeia, câmara e júri abrigasse os feridos de guerra por algum tempo, além da também já citada propaganda de alistamento para o corpo de voluntários da pátria.

\section{O Público e o Privado}

O curador de Sabina, João Carvalho de Barcellos, escreveu durante o processo uma carta de apelação sobre a sentença a que a ré havia recebido. Considerada culpada, foi sentenciada a 1 mês de cadeia e multa correspondente a metade do tempo, e com os agravantes mais 25 açoites e obrigada a trazer no pescoço um argolão por 15 dias. Na carta feita por João Barcellos, fica claro que o motivo a que se estava recorrendo era pelo dano que a sentença causaria ao senhor de Sabina, e não pela crueldade de se carregar ao pescoço um argolão, além dos açoites.

Moreira ao analisar os motivos das prisões em Porto Alegre percebeu que grande parte se deu com as chamadas "desordens, insultos e imoralidades", além destas, alguns senhores solicitavam a prisão de seus escravizados que considerassem atrevidos e desobedientes. Estas características, são consideradas agravantes por "roubar o tempo de serviço pertencente ao senhor" (MOREIRA, 2003, p. 31). Questão esta que pretendo abordar neste item.

A carta do curador traz diversos motivos para que Sabina fosse livrada da prisão de 1 mês e demais punições físicas, considerou uma pena muito severa, dentre os motivos pelo fato de Sabina já ter sido castigada pelo senhor: "Conto pois ter cumprido o meu dever e que a ré castigada como se acha já não só pela prisão que sofreu, como pelo processo a que respondeu, do castigo que the infringiu seu senhor, como é notório, [seja] absolvida". . Outro ponto que o curador roga ser revisto é o atenuante do artigo $3^{\circ}$ do código criminal, afirmando que Sabina cometeu a injuria por ignorância. Não fica claro durante o processo, mas aparentemente Justino também retribuiu as ofensas da preta. $\mathrm{O}$ artigo terceiro diz o seguinte: "Não haverá criminoso, ou delinquente, sem má fé, isto é, sem conhecimento do mal, e intenção de o praticar ${ }^{10 "}$.

A justificativa, portanto, era de que Sabina havia praticado tal injuria por ignorância, e não tinha consciência do ato que cometeu. Aliar o escravizado a esta falta de consciência era comum, como forma de justificar algumas ações que fugiam a lei. Mas vamos nos deter por hora à questão da sentença. $O$ curador frisa que a pena havia sido exagerada, pois Sabina já tinha passado 24 horas na cadeia, após sua prisão em flagrante, pelo exaustivo processo, e por último, por já ter sido castigada pelo próprio senhor como é notório. A palavra "notório" empenhada pelo

\footnotetext{
${ }^{9}$ Processo Criminal. APERS. N 3127, M 8, E 56. p. 19 v e 20. ${ }^{10}$ Código Criminal do Império do Brasil, 1830. Disponível em: http://www.planalto.gov.br.
} 
curador pode significar que eram visíveis as marcas do castigo a que havia sido submetida, logo, o senhor que era o proprietário daquela mulher, e que por direito tinha a posse dela, já havia aplicado as penas que achava necessárias.

Neste ponto retomamos a questão do "roubo do tempo de serviço pertencente ao senhor". Ao prender Sabina durante 1 mês, por um crime que o senhor ou pelo menos o curador já julgava ter sido castigado, a punição se estenderia ao senhor, que ficaria privado do lucro e dos serviços da mesma durante um período longo. Outro ponto de vista que merece ser incluído nesta discussão, diz respeito a intromissão do Estado nas relações privadas. Ao tirar do senhor o direito de punir o escravizado, e também ampliando para a esfera pública, este poder senhorial ficaria abalado ${ }^{11}$.

Sidney Chalhoub aborda uma questão importante a partir do conto de Machado de Assis sobre a história de Pancrácio: a "falência da política de domínio". Segundo o autor, ao referir-se às críticas de Machado: "há o conflito entre os princípios da primazia da liberdade e da defesa irrestrita do direito de propriedade privada. Esse é um dos eixos fundamentais do debate a respeito do encaminhamento político que se devia dar à "questão servil' na segunda metade do século XIX" (CHALHOUB, 2011, p. 121). Neste caso a discussão gira entorno da liberdade e da alforria. Como ele retomou ao longo da pesquisa através dos processos de liberdade feito pelos próprios escravizados. Mas, para além da questão da liberdade, o que o autor nos chama atenção é para o fato de que a instituição escravista perdia aos poucos seus poderes, para passar ao Estado o direito de propor medidas de uma abolição gradual, bem como de interferir no direito à propriedade privada dos senhores.

Thompson estudou as relações de costumes, cultura e tradições populares do século XVIII inglês ${ }^{12}$, e a partir disto elaborou um conceito de "costume" que remetia à uma prática comum, de longa duração

11 O nome do senhor era Antônio Ferreira de Vasconcelos, ainda estão sendo levantadas mais informações sobre ele.

12 THOMPSON, E. P. Costumes em comum. São Paulo: Companhia das Letras, 1998. e que tomava o peso de lei. Se formos pensar neste conceito, em uma adaptação para o nosso contexto, sem querer forçar estas aproximações, podemos pensar que, ainda que houvesse uma lei que respaldasse de fato o direito privado do senhor sobre o escravizado e permitia que este aplicasse castigos moderados, era comum que o Estado não interferisse nestas relações. Como vimos, a segunda metade do século XIX caracterizou-se pela perda do poder privado mediante a interferência do Estado, uma perda da legitimação deste costume que justificava e respaldava 0 poder do senhor de castigar 0 escravizado. Dito de maneira mais clara e direta, independentemente de haver uma lei que autorizasse os castigos moderados, o costume já legitimava o direito do senhor de o fazer, fosse moderado ou não.

Outro conceito que guardadas suas especificidades pode contribuir para esta análise é o de "justiça negociada", abordado por Maíra Vendrame (VENDRAME, 2016, p. 32). Este conceito é atribuído às práticas de justiça comunitárias entre os imigrantes italianos no Brasil, como forma de resolução interna de desequilíbrios causados por crimes ou desavenças dentro da comunidade. Como forma de "recomposição do equilíbrio social", o castigo empenhado pelo senhor, e não pelas mãos do Estado, era uma forma de resolução interna destes crimes, uma vez que mantinha nas mãos do senhor o poder de decisão e de empregar o castigo considerado necessário. Há ainda a discussão sobre o viés do cativo, que poderia considerar injusto a punição empenhada pelo senhor, e poderia recobrar isto de outras formas, como práticas de resistência e agência. Não raras vezes o resultado de um castigo considerado injusto foi a morte de um capataz, do senhor, fuga, a recorrência ao Estado como vias de proteção aos maus tratos ou alguma outra forma de resistência.

\section{Os códigos reguladores}

No século XIX foram criados, nos municípios, conjuntos de normas que tinham como objetivo formalizar práticas e relações, os chamados Códigos 
de Posturas Municipais ${ }^{13}$, eram elaborados por autoridades locais, que visavam regular o convívio, criando meios de punição para práticas consideradas lesivas para o bem-estar público e moral. Em Cachoeira temos um capítulo específico do código que versa sobre a moral e os bons costumes:

Offensas a moral e bons costumes.

Artigo 96. O ébrio que vagar pela rua ou praça além da pena de ser posto em custodia durante a bebedia, será multado em 10 mil reis e no duplo nas reincidências.

Artigo 97. Todo aquelle que dér gritos, fizer alarido ou proferir expressõens injuriosas, infamantes ou indecentes nas ruas ou praças, será multado na quantia de 10 mil reis, além da pena em que incorrer pelas injurias que proferir.

Artigo 98. Também incorrerá nas penas de artigo antecedente:

$\S 1 \%$. O que se apresentar em público ou em lugar que possa ser visto, com gestos e acçoens indecorosas e offensivas a moral e decencia das famílias.

$\S 2 \div$. O que escrever palavras obscenas ou figaras deshonestas nas paredes, muros ou qualquer que possa ser visto.

Sabina infringiu uma regra cara ao convívio que previa a manutenção da moral e dos bons costumes, além de proferir palavras indecorosas, as dirigiu à uma autoridade, um Guarda Nacional. Como nos referimos anteriormente, há uma suposição de que a cobrança tenha sido feita durante o turno da manhã, caso Sabina estivesse circulando pelas ruas tarde da noite deveria trazer consigo uma autorização, do contrário ainda poderia receber mais um agravante na pena. Segundo este código, os que andassem na rua depois do horário de silêncio deviam ter "bilhete de seu Senhor, receita para botica, ou lampião aceso, o que for encontrado sem estes requisitos será levado a casa de seu Senhor sendo dentro da Villa, e no caso contrário será recolhido a Cadeia até ser procurado pelo seu Senhor".

Em geral, nas regulamentações que versavam sobre a limitação de circulação de escravizados determinava que caso fossem apanhados, a ordem era de que fossem encaminhados à cadeia até o resgate do senhor. Também havia as opções de que as multas fossem

13 Livro $1^{\circ}$ de Posturas Municipais de Cachoeira. Códice CM/S/SE/RPL, Arquivo Histórico de Cachoeira do Sul. comutadas em açoites, uma saída "bem mais agradável" ao bolso do proprietário, apesar de que também demandaria que o trabalhador escravizado ficasse impossibilitado de exercer seus ofícios durante alguns dias, se recuperando das correções recebidas.

O Código Criminal de 1830, assim como o Código de Posturas municipais, carregava fortes questões morais e buscava delimitar aquilo que feria ou não estes princípios morais de conduta. Sabina foi incursa nas penas do artigo 237, parágrafo 3ํㅡㄴ combinado com o artigo 238 do código criminal, isto quer dizer que, além de ser incursa no crime de injúria contra empregado público ou pessoas particulares, esse preceito jurídico faz referência a uma injuria verbal. Dadas as proporções de tais artigos, talvez a preta ainda tenha tido uma pena leve, uma vez que não foi levado em consideração que tais injúrias foram cometidas pelo oficio de Justino, e sim pelo fato dele estar devendo os vinténs mencionados. Ainda foram atenuantes os parágrafos 7 e 8 do artigo 18, que fazem referência a provocação precedentes de Justino às injúrias de Sabina.

O curador usa como forma de corroborar a necessidade da reformulação da pena a seguinte afirmação:

\begin{abstract}
Além de tais circunstâncias que muito concorreram para esta apelação, ocorreu-me também diversos exemplos que vi darem-se na Corte do Império e que são a prova de o fato da prisão em flagrante delito não tem por consequência a fatura do processo por injurias verbais; e como o ofendido não era empregado público em ato do exercício de suas funções, entendo que terá falta de competência no juízo para fazer o processo ex-ofício ${ }^{14}$.
\end{abstract}

Provavelmente, ao fazer referência sobre os costumes da Corte, seria uma forma de demonstrar 0 atraso no tratamento das leis e penas que as vilas interioranas tinham, além de claro, mostrar que este profissional do direito tinha mobilidade, experiência e conhecimento sobre o que se praticava noutros meios importantes. O curador tenta apelar dizendo que Justino não estava em exercício da função na ocasião

\footnotetext{
${ }^{14}$ Processo Criminal. APERS. N 3127, M 8, E 56. p. 19 v e 20.
} 
do delito, mas como vimos isso não modifica os atenuantes que colocavam a injuria como crime indiferente de ser empregado público ou pessoa particular. Contudo, Justino não recebeu uma punição conhecida neste processo, levando em consideração que também proferiu injúrias a Sabina, ato este, inclusive, condenado no código de posturas municipais, como visto.

No dia 23 de dezembro de 1867 os 25 açoites foram aplicados a preta Sabina na cadeia da cidade, que devia estar por estes dias iniciando o cumprimento da pena de 1 mês de prisão, tendo em vista que a negação da apelação havia sido assinada três dias antes. Uma pena dialogava com a outra no cotidiano da correção daquela mulher africana escravizada, afinal, os 25 açoites que lanharam o seu corpo (e machucaram a sua honra) provocaram lesões que foram curadas na cela da cadeia ao longo daquele um mês de reclusão.

\section{Considerações finais}

A necessidade de colocar Sabina e Justino dentro do contexto nacional pode nos ajudar a interpretar as ações que se seguiram no documento judiciário montado como resultado do atrito entre os dois. Como caracterizou Luiz Rossi em seu estudo sobre Édison Carneiro, faz-se necessário abordar o contexto em que os sujeitos focos de nossa análise estão inseridos e o meio pelo qual foram moldados. $O$ autor ressalta a importância do "capital simbólico" acionado pela família de Carneiro em busca de uma inserção social, tratando-se de pessoas negras em um período pós abolição, que puderam contar com o apoio de uma elite política local em vias de se afirmar. Tal como Aurélio de Bitencourt abordado por Moreira em artigo que estuda a trajetória de um homem negro que teve sua inserção social facilitada pela rede de sociabilidade que construiu e herdou ${ }^{15}$.

Sabina, podemos imaginar, devia ter uma mobilidade interessante dentro daquele espaço, uma

15 MOREIRA, Paulo Roberto Staudt. O Aurélio era preto: trabalho, associativismo e capital relacional na trajetória de um homem pardo no Brasil Imperial e Republicano. Estudos IberoAmericanos. PUCRS, v. 40. 2014. vez que pôde se deslocar para a cobrança da dívida. Também é interessante notar que no interrogatório ela diz conhecer o guarda nacional Justino, portanto as pessoas com as quais se relacionava ia para além do espaço da propriedade do senhor e do cativeiro, que não pudemos apurar se ficava na área central ou rural da cidade, mas mesmo assim indica que havia a possibilidade de mobilidade e de interação com indivíduos de outras esferas sociais.

Tentamos aproximar o contexto em que Sabina e os outros personagens estavam inseridos no momento em que o processo se deu. Percebemos que além da Guerra do Paraguai, que foi um acontecimento que permeou as relações do período, o censo de 1872 também caracterizou uma espécie de fotografia, em uma comparação, talvez, pouco adequada, da vila de Cachoeira. O censo é extremamente interessante para compreender as relações, e quem eram os indivíduos que compunham aquele espaço, e em uma abordagem futura merece maior atenção. Ainda sobre o contexto, foi empreendido o esforço de aproximar o debate abolicionista e as movimentações da época, ao discurso e entrelinhas do processo.

Como diz Levi, o fato em si é pouco importante, outros tantos podem ter ocorrido, mas foi a partir dele que pudemos delinear um aspecto maior da sociedade, dos discursos e dos indivíduos que a compunha. Naquele ano de 1867, o cenário da Guerra do Paraguai deve ter ressaltado as figuras militares locais, aliado a maior interferência do Estado nas relações privadas, resultou para Sabina uma pena bem severa quanto aos castigos físicos, e como tentamos provar, uma "punição" por consequência ao senhor também, ao ser privado do lucro proveniente do trabalho da escravizada.

Apesar de se ter focado os prejuízos do senhor em grande parte do texto, Sabina foi a maior prejudicada no processo. Como informamos, apesar de ter sido notório que Justino praticou injúrias à preta, isto não gerou qualquer tipo de punição que tenha sido mencionada no documento. Ao justificar a atitude de Sabina como uma resposta ao Guarda Nacional, o curador recebeu a seguinte resposta: que 
tal ato não anulava o fato nem eximia Sabina da culpa de ter injuriado um Guarda Nacional. Fica claro, portanto, que a questão estava diretamente ligada ao status social de Sabina e Justino. E provavelmente mais ainda, a honra da própria instituição da Guarda em tempos de tanta ascensão da classe.

Além da condenação pautada por um contexto de escravidão, uma das alegações ditas nos interrogatórios foi de que Justino já havia pago a quantia que devia a Sabina. Isso parece pouco lógico, uma vez que o risco de ser presa ou receber algum castigo deve ter sido considerado quando Sabina foi cobrar o valor do guarda. Das 5 testemunhas, ao menos 4 eram Guardas Nacionais que estavam na cadeia em serviço no momento do acontecido, apenas uma ficou ilegível, as testemunhas foram: Ezequiel Rodrigues Florence, o comandante que deu voz de prisão para Sabina, 21 anos, natural e residente em Cachoeira, solteiro; Januário Olímpio de Oliveira, 45 anos, sentinela da cadeia, natural de local ilegível mas residente em Cachoeira (este foi o guarda que aconselhou Sabina a se retirar do local antes de ser presa); Antônio Alves da Silva, natural do Rio de Janeiro, residente em Cachoeira, faz parte do comando policial da cadeia, de 53 anos de idade; José Joaquim Cidade, 54 anos, natural desta província e morador em Cachoeira, a atuação ficou ilegível; e por último José da Cunha, de 54 anos, solteiro, e tenente da cadeia.

Todas testemunhas repetem a mesma história, que a ré injuriou a vítima de corno, filha da puta e ladrão, ao que ele informou já ter pago as quantias e a mesma recebeu ordem de prisão. O que parece mais absurdo no processo é que durante o interrogatório, Sabina foi questionada do porquê não ter procurado o comandante da cadeia para tentar resolver a situação, e fazer com que o guarda pagasse a quantia sem ter que recorrer aos insultos. Sabina responde que não o fez por não conhecer o comandante. Parece irônico que um julgamento que tenha recorrido a testemunhas que pudessem corroborar com a versão da vítima, pensasse que de fato o comandante acreditaria na versão de Sabina. Apesar da versão do curador de que a condição de
Sabina a impelisse a agir com ignorância e falta de consciência, parece muito claro o motivo que levou Sabina à cadeia naquele dia: precisava cobrar o dinheiro que Justino Ihe devia, provavelmente foi uma medida de desespero, imagino ainda que a ré dependesse da quantia para resolver alguma pendência, o pagamento de aluguéis ao senhor, por exemplo.

O dia em que Sabina insultou o Guarda Nacional Justino, e o injuriou de corno, filho da puta e ladrão, ficaram marcadas na história. Nós, no entanto, não sabemos ainda o que aconteceu com Sabina depois de findo o processo, sabemos, contudo, que foi uma atitude que demandou muita coragem, afinal, era uma africana que vivia há pelo menos 17 anos no Brasil e devia conhecer bem a sociedade da qual fazia parte, percebendo os limites de atuação, mas foi no dia que ultrapassou os limites, e que procurou cobrar aquilo que lhe era justo, que sua figura ficou marcada.

\section{Referências}

ARAÚJO, Thiago. Escravidão, fronteira e liberdade: políticas de domínio, trabalho e luta em um contexto produtivo agropecuário (Vila da Cruz Alta, Província do Rio Grande de São Pedro, 1834-1884). Porto Alegre, Dissertação (Mestrado em História). PPGH-UFRGS, 2008

BOTELHO, Tarcísio R. Censos e construção nacional no Brasil Imperial. Tempo Social. Revista de Sociologia da USP, São Paulo, v. 17, n.1, p. 321-341, 2005.

BOTELHO, Tarcísio R. População e nação no Brasil do século XIX. USP: 1998. Tese de Doutorado em História;

Censo Nacional de 1872.

CHALHOUB, Sidney. Visões da liberdade: uma história das últimas décadas da escravidão na Corte. São Paulo: Companhia das Letras, 2011.

Código Criminal do Império do Brasil, 1830. Disponível em: http://www.planalto.gov.br.

Código de Posturas Municipais de Cachoeira, século $\mathrm{XIX}$.

GINZBURG, C. O Queijo e Os Vermes. São Paulo: Companhia das Letras, 2006. 
GINZBURG, Carlo. O inquisidor como antropólogo. In: O fio e os rastros: verdadeiro, falso e fictício. São Paulo: Cia das Letras, 2007.

GINZBURG, Carlo. Os Andarilhos do Bem. Feitiçaria e cultos agrários nos séculos XVI e XVII. São Paulo, Cia. das Letras, 2010.

GOMES, Ângela de Castro. Nas malhas do feitiço: o historiador e os encantos dos arquivos privados. Estudos Históricos, Rio de Janeiro, FGV/CPDOC, v. 11, n. 21, p. 121-127, 1998.

GRAHAM, Sandra Lauderdale. Caetana diz não: histórias de mulheres da sociedade escravista brasileira. São Paulo: Companhia das Letras, 2005.

GRINBERG, Keila. A história nos porões dos arquivos judiciários. In: PINKY Carla Bassanezi;

LUCA, Tania Regina (org). O historiador e suas fontes. São Paulo: Editora Contexto, 2009.

MOREIRA, Paulo R. Staudt. Os cativos e os homens de bem: experiências negras no espaço urbano: Porto Alegre, 1858-1888. Porto Alegre, EST, 2003.

MOREIRA, Paulo Roberto Staudt. O Aurélio era preto: trabalho, associativismo e capital relacional na trajetória de um homem pardo no Brasil Imperial e Republicano. Estudos IberoAmericanos. PUCRS, v. 40, n. 1, p. 85-127, jan.-jun. 2014.

MOREIRA; MÜGGE. Histórias de escravos e senhores em uma região de imigração europeia. São Leopoldo: Oikos, 2014.

MÜGGE, M. H.. Guarda Nacional e seus comandantes: sociedade e milícia na bastarda do Império Rio Grande do Sul (1845-1873). In: Moreira, P. R. S. et al.. (Org.). Instituições e práticas de controle social: perspectivas de pesquisa. 1ed.Oikos/Unisinos: São Leopoldo, 2016.

MÜGGE, M. H.. Prontos a contribuir: guardas nacionais, hierarquias sociais e cidadania (Rio Grande do Sul - século XIX). 1. ed. São Leopoldo: Oikos, 2012. (Dissertação de mestrado)

PERUSSATTO, Melina. Como se de ventre livre nascesse: experiências de cativeiro, parentesco, emancipação e liberdade nos derradeiros anos da escravidão - Rio Pardo, RS, c.1860- c.1888. São Leopoldo, Dissertação (Mestrado em História), PPGHUNISINOS, 2010.

Processo Criminal. APERS. N 3127, M 8, E 56.

ROSSI, Luiz Gustavo Freitas. O intelectual "feiticeiro": Édison Carneiro e o campo de estudos das relações raciais no Brasil / Luiz Gustavo Freitas Rossi. Campinas, SP, PPGAS, 2011.

THOMPSON, E. P. Costumes em comum. São Paulo: Companhia das Letras, 1998.

TORAL, A. A.. A participação do negro escravo na guerra do Paraguai. Estudos Avançados, v. 1, p. 1, 1995.

VARELLA, D. Estação Carandiru. São Paulo: Companhia das Letras, 2005.

VARGAS, J. Pelas margens do Atlântico: um estudo sobre elites locais e regionais no Brasil a partir das famílias proprietárias de charqueadas em Pelotas, Rio Grande do Sul (século XIX). UFRJ: Rio de Janeiro. 2013. (Tese de doutorado)

VENDRAME, Maíra Ines. "Questões de feitiço": quando a crença em bruxaria vira violência entre famílias camponesas italianas (Brasil e Itália, século XIX). Navegar. vol. 2, no 2, Jan.Jun. 2016, pp. 66-85. (Dossiê: Italianos no Brasil: imigração e retorno)

VENDRAME. Maíra Ines. O Poder na Aldeia: redes sociais, honra familiar e práticas de justiça entre os camponeses italianos (Brasil-Itália). São Leopoldo: OIKOS, 2016.

WITT, Marcos Antônio. Excepcionais normais? A(s) trajetória(s) de três pastores no Sul do Brasil (1824-1893). História Unisinos. 20(3):287-299, Setembro/Dezembro 2016. 